\title{
The philosophical worldview of Nasiridin Tusi
}

\author{
Kushshayeva Nafisa Mansurovna ${ }^{1}$ \\ ${ }^{1}$ BukhSU "National idea, bases of spirituality, Teacher of the Department of Law and \\ Education, Uzbekistan
}

Email:kushshayeva_n@buxdu.uz

\begin{abstract}
This article analyzes the philosophical outlook of Abu Ja'far Muhammad ibn Muhammad ibn Hasan Nasiruddin Tusi, who lived in the 13th century, recognized as the greatest philosopher and philosopher in the history of philosophy and mysticism, who left an indelible mark on the development of Islamic philosophy. It also provides an overview of the main issues in the philosophical and philosophical views of Nosiriddin Tusi.
\end{abstract}

Keywords: Nosiruddin Tusi, Aristotle, Tusiye Philosophy, Awsaf-ul Ashraf, Sayr ul-suluk.

\section{INTRODUCTION}

Reforms in the country are being continued to comprehensively study and promote the scientifictheoretical heritage of great thinkers, to educate the younger generation in the spirit of the noble traditions of our ancestors. The need to increase the effectiveness of the reforms in the spiritual and educational sphere calls for a qualitatively new level of work in this area. Therefore, "we follow the traditions of the wisdom of our ancestors and understand their ideas, and we are carrying out radical reforms, and we are on the way to form a new image of our country." In this regard, the scientific-theoretical analysis of the contents of Tusiy's world-renowned ideology of upbringing of young people, such as high spirituality, high spirituality, purely philosophical thinking, and upbringing of a perfect person, is important.

Most of the philosophers of the time of Nosiriddin Tusi (1201-1274) were associated with Aristotle and partly by Plato. Not only in the East, but also in the Western world, peripatetics have supported Aristotle's metaphysics. The natural worldview also had its source. The philosophy of the philosopher, based on Greek philosophy and theory, which is the basis of Eastern philosophy, is said to consist of four elements: fire, water, soil and air. According to him, matter never disappears, but it shifts from one form to another. His views on life are in agreement with those of Farabi, Ibn Sina and Bahmanyar. All that is present in the Tussi heritage is divided into two parts: the necessary existence and the possible existence.

\section{THEORETICAL BACKGROUND}

The cause of the whole being, the world, the nature and the thought is a necessary being. This necessary existence arises from the creation of the world of truth. According to the scholar, there is no creator and effector of the necessary existence. The necessary existence does not need any reason. The Creator is the one who created all things. He, with his closeness to idealism, understands nothing but God as a necessary being. He believed that this view was more in line with the views of Islamic theologians, and that it was impossible to describe the philosophic existence with such an understanding. According to the philosophical considerations, there is no difference between the existence of the substance and the existence of the being.

In Ibn Sina and Bahmanyar's view of the existence of matter, it states that matter, by its essence, can never be a cause. According to Tusi, the reason for the whole being is the necessary existence, the necessary being at the same time. Necessary non-physical beings never die because there is no difference between their existence and their existence. The necessary existence is neither beginning nor end. There are several factors that influence the onset of possible existence. For this reason, the beginning is not the beginning of everything, but the beginning of the possible existence. And the reason for the whole result is the Unified Being, which is the beginning of everything, or the one that forms it. 
Although the philosopher's views on the necessary existence have something in common with the Islamic theologians' perceptions of Tawheed, Fahriddin Razi has criticized the views of the peripheral. Tusius, however, believes that such popular views as Fahriddin Razi are illogical and groundless. In the understanding of Razi, if the duty is to use the meaning of "existence," it can never be used for existence. Tusius dismisses this idea as insignificant and says that closeness is only with the concept of "existence," but there are many differences between what is obligatory and what is possible.

\section{MAIN PART}

According to the philosophical considerations, there is a great difference between the physical nature of the body and the nature of the being. Commenting on the existence of a mental being between the essence of the being or the existence of the substance, the essence does not exclude the existence of the mind alone. It considers the condition of existence of essence to be a movement and gives a specific explanation of the difference between the natural and artificial forms of movement and what the difference is.

In the central object of Nosiruddin Tusi's philosophical worldview, the problem of "perfect man" is at the forefront. This was the basis of the themes raised by Sufi teachings in the 13th century. Tusi is also one of the thinkers who enjoy this philosophy. "Al - man al - perfect", that is, perfect person, "Al man al - judge", that is, the problem of awake man was the main topic raised by Sufis. That is, in the 11th-12th centuries, Abu Hayyan al-Tauhidi, rightly and wisely, found out that "Ashkala-l-al-man," that is, a man who freely and freely thought, began not only to speak, but also to express theory and had become a practice problem.

The notion of "al - man al - perfect" was first used in the Islamic world by the famous Arabic scholar Muhyiddin Abu Abdullah Muhammad ibn Ali al-Hatami - toi ibn Arabiy (1163 - 1240). put forward their views. Nosiruddin Tusi commented on this issue too. One of the main inspirations of the thinker in the World Oriental Studies is that Shahobiddin Yahya Suhravardi's philosophy of "Ishaq" was greatly influenced.

According to Tusi, everyone can lose their negative traits. To do this, one must return to the Truth and rely on the power of reason and thinking. If man does not understand why he came to this world, then he does not understand himself, nor does he know where the true path is. The mind is only given to distinguish good from evil. Like the Sufis, Tusi believes that he can attain perfection according to the way he cultivates his own soul. "Whoever knows that the world is temporary, he can avoid the evil of the world and not be deceived by it. Anyone who is able to nurture his nafs and avoid the danger of becoming a slave of God, can go on the path to the Truth.

Tusi's view is that human perfection, the perfection of a human being, is an obstacle to the perfection of a human being, above all, the animal's dreams and desires. The reason for the individual's ability to work independently and freely is to have a sense of it.

In his work, "Nasiriy Nosiri," Nosiriddin Tusi exemplifies the ways in which a person can be freed from animalistic features and brought up as a perfect human being. His views in this regard are also reflected in the work of Awsaf-ul-Ashraf. He advises people to put their faith in God. As a person who is perfect, he points out that the scientist should pay attention to the spiritual aspects, not the material. Providing spiritual requirements for anyone who wants to become a perfect person is one of the most important factors. As a result of knowledge and practical activity of a person there is a factor of its completion. The perfect man is prone to eternal bliss, and at this time he finds spiritual pleasure.

\section{DISCUSSIONS}

According to the thinker, the process of human perfection is not a mere process. This nonphytetic process is manifested in the combination of scientific and practical activities in life. In his view, there is no value in the perfection of a man who has turned from the way of God and who has been given the goods of the world. It is the struggle of the nafs to complete one's self, to trust and worship God with sincere heart. That is why he says that prayer purifies the heart and fills it with pure feelings. The mystical work of Tusiye on his perfect man tries to explain in a more profound language the seyr-ul-suluk. As for Sufi Sufi, it is said that man can reach the level of perfection by means of a leech. "Everyone who follows mysticism (tax) goes the path of perfection, first of all, of the Shariah and then of the truth. The 
psychological state of mind. And status is the level of perfection that Sufis have achieved in the shade of Jiddu. According to the philosophy of mysticism, a person who strives for spiritual perfection must pass through the status and status of the tax. When he begins to nurture a single material body that is on its way to perfection, his soul can be freed from its ugly traits and fattened up to a higher level. As it is seen, the scholar does not want to understand human perfection in religion when explaining the problem of a perfect human being.

In his view, a perfect person has an attitude towards all religions and should respect the peculiarities, habits and traditions of these religions. He also advises that a perfect person be cautious in matters of religion and sect. In his view, religious affiliation is one of the fundamental elements of human thinking. The perfect human being relies on scientific, moral, practical, and religious principles. He sees all the spiritual defects and the moral defects that humans have. He notes that physical weakness is the primary argument for human weakness.

\section{CONCLUSION}

In summary, Nasiruddin Tusi's view of the perfect man is a factor of justice, the principle of fairness in the stability of human-human and human-society relations. With his justice and humanistic activities, a perfect person can set an example for the environment.

In his philosophical considerations, Nasiruddin Tusi continued to pursue Aristotle's traditions and sought to show that rationalism and sensualism play both roles in the matter of truth.

\section{REFERENCES}

1. Mirziyoev Sh.M. Speech at the 72nd Session of the UN General Assembly // - Tashkent, 2017. No. 196.

2. Muminov A.K. Hanafi madhhab in the history of Central Asia / edited by S.M. Prozorov. Almaty: Kazakh encyclopedias, 2015.

3. Muhammad Mudarrisi (Zinjani). Philosophical views of Haji Nasiriddin Tusi. Tehran, 1363.

4. Nasiriddin Tusi. Cyrus Suluk. Compiled and translated by English. text by Sayyid Jalal Husayn Badakhshoni. London, 1998. - Persian, and ang. lang

5. Nasirüddin Tusi. Ahlak-1 Nasıri. Istanbul: Fecr Yayınları, 2005.

6. Tusi Nəsirəddin. Övsafül Đşraf. Bakı, 2010. 